\title{
Leadership and supervision in pre-service Economics and Accounting teacher education in Portugal
}

\section{Ana Luísa Rodrigues}

Instituto de Educação da Universidade de Lisboa, Portugal, alrodrigues@ie.ulisboa.pt

\begin{abstract}
The process of leadership and pedagogical supervision in preservice teacher education is a determining factor in the relationship that needs to be established between the higher education institution (HEI) and the cooperating school (CS) where the future teacher carries out his supervised pedagogical practice.
\end{abstract}

This study intends to analyze this process of leadership and supervision, understanding this relationship in a perspective of effective collaboration, reflection and sharing of practices, assuming the teacher of the CS as a fundamental element of the process.

Based on this assumption, it will be important to provide teaching and learning situations with individual and joint reflections, in order to promote autonomy and shared interaction, contributing to professional development and to the co-construction of knowledge.

Methodologically, this is a case study with participant observation, within the scope of the Master's Degree in Teaching Economics and Accounting of the Institute of Education of the University of Lisbon, the only master's degree in Portugal that gives professional qualification for teaching in secondary education in Economics and Accounting.

With this study hope to obtain a characterization of the leadership and supervision process developed and to delineate the main functions of the mentor teacher as a fundamental part of the process of collaborative supervision, in the context of the current model of teacher training.

Keywords: Leadership, supervision, preservice teacher education, economics and accounting education. 


\title{
Liderança e supervisão na formação inicial de professores de Economia e Contabilidade em Portugal
}

\begin{abstract}
Resumo
O processo de liderança e supervisão pedagógica na formação inicial de professores é um aspecto determinante na relação que é necessário estabelecer entre a instituição de ensino superior (IES) e a escola cooperante (EC) onde o futuro professor efetua a sua prática pedagógica supervisionada.
\end{abstract}

Neste estudo pretende-se analisar este processo de liderança e supervisão, compreendendo esta relação numa perspetiva de efetiva colaboração, reflexão e partilha de práticas, assumindo-se o professor da EC como elemento fundamental do processo.

Partindo deste pressuposto, será importante proporcionar situações de ensino e aprendizagem com reflexões individuais e conjuntas, no sentido de promoverem a autonomia e a interação partilhada, contribuindo para o desenvolvimento profissional e para a co-construção de conhecimento.

Em termos metodológicos trata-se de um estudo de caso com observação participante, no âmbito do Mestrado em Ensino da Economia $e$ Contabilidade do Instituto de Educação da Universidade de Lisboa, único mestrado em Portugal que confere a habilitação profissional para a docência no ensino secundário na área da Economia e Contabilidade.

Com este estudo espera-se obter uma caracterização do processo de liderança e supervisão desenvolvido e delinear as principais funções do professor cooperante como parte fundamental do processo de supervisão colaborativa, no contexto do atual modelo de formação de professores.

Palavras-chave: Liderança, supervisão, formação inicial de professores, ensino da Economia e Contabilidade. 


\section{Introduction}

The pedagogical supervision process, in the current preservice teacher education model in Portugal, is prefigured as an usual and fundamental procedure, a process that contributes strongly to the construction of the professional identity of a future teacher, according to Izadinia (2015).

In this sense, this study intends to analyze the leadership and supervision process, understanding this relationship in a perspective of effective collaboration, reflection and sharing of practices among the various stakeholders, considering the university teacher, but especially focusing on the relationship between the preservice teacher and the mentor teacher of the cooperating school (CS).

Associated with this process, evaluation is a complementary and indispensable component. In this case, a predominance of formative evaluation is sought, based on the assumption that collaboration can foster reflection and provide situations of mutual learning.

In this way, it is intended to characterize the leadership and supervision process developed within a Masters in Teaching at the University of Lisbon, and to outline the main functions of the mentor teacher as a fundamental part of collaborative supervision process in the preservice teacher education.

\section{The leadership and pedagogical supervision process in pre-service teacher education}

When we approach the topic of leadership and pedagogical supervision we find the term "clinical practice". In addition to the parallel that can be established with the medical field, this concept was mainly intended to highlight particular characteristics attributed to professional training (Burn, \& Mutton, 2015). In this sense, these authors consider that preservice teacher education programs should not be interpreted merely as spaces to learn through experience or by imitation of the more experienced teachers, with pre-specified classroom routines. "Clinical practice" presupposes that preservice teachers engage in a research process, based on various sources of knowledge, including research and data collection, in order to acquire interpreting skills, in particular the intervention and implementation of pedagogical actions and evaluation of results.

Nonetheless, Mena, Hennissen, and Loughran (2017) point to the importance of selflearning through experience in knowledge acquisition, in relation to learning through the 
guidance of more experienced teachers, however they consider that the support of these mentor teachers is crucial in the knowledge of the practice and professional development of the teachers in formation.

The study carried out by these authors found that the level of participation of the mentor teachers in the creation of knowledge was generally high, which may indicate the relevance of the first experiences of the preservice teachers and how their learning can be promoted through the advice of the experienced teachers. It is also suggested that less directivity of these, offers greater opportunity for preservice teachers to acquire higher level knowledge.

Bond (2011) argues that the concept of teacher leadership should be introduced in initial training, and teacher training programs, under the guidance of mentor teachers, are the ideal place to begin to develop the knowledge and skills of teachers in training by providing them with a leadership framework. By starting this process early in their careers, they will be better prepared to take increasingly consistent roles at the leadership level.

On the other hand, Izadinia (2015) found that, although mentor teachers did not create very significant changes in the professional identity of the preservice teachers, they can influence them positively or negatively. In this way, when the orientation relationship is positive and the expectations of the preservice teachers are reached, they tend to obtain a higher level of confidence in their capacities as a teacher, which can have a significant impact on the construction of their professional identity.

Vieira \& Moreira (2001), refers to some supervisory strategies that can be mobilized, namely, self-questioning or self-assessment, reflexive dialogue, documentary analysis, inquiry, observation of classes, professional narratives, teaching portfolio and action research; which correspond to the following instruments: questionnaires, field notes, reflexive records, audio and video recordings, grids and scripts.

One of the strategies most used in preservice teacher education programs around the world is peer coaching, aiming to improve teachers' professional practices and development, according to $\mathrm{Lu}$ (2010). In this case, from a perspective of expert coaching, where more experienced teachers support teachers in training (Ackland, 1991 quoted in Lu, 2010). In this strategy, class observation is very important, which normally includes three main phases: pre-observation, observation and post-observation, where in order to make the observation cycle operational, time is required for teachers to gather before and after class.

According to the same author, for the development of this strategy, it is important to guarantee three conditions: a) a programmatic vision that believes in the strategy potential for the development of future teachers, b) an organized, balanced and significant program, and c) an implementation phase followed by constant evaluation (Lu, 2010). 
Regarding the evaluative issue associated with the pedagogical supervision process, some relevant ethical guidelines are also highlighted, which allow us to support procedures for a fair assessment. These should obey the following principles: rigor about the normative framework, principles and objectives; clarification on the role of each player involved in the assessment relationship; diversification of observation and information collection strategies; and transparency in the presentation and use of the collected information, based on intelligibility schemes of practical knowledge (Batista, 2011).

\section{The role and functions of the mentor teacher}

The mentor teacher is one of the key elements of the leadership and supervision process, in which it is intended to promote reflective and collaborative capacity, so that it contributes to the autonomy of the preservice teachers, the construction of professional knowledge and the improvement of quality of education, according to Azevedo (2012).

Vieira (1993) describes five general functions of the mentor teacher: i) to inform: its primary function is to provide relevant and updated information, in the scope of supervision, observation and didactics, according to the teacher training objectives and needs; ii) to question: must be able to problematize, questioning the reality that observes, equating the problems of practice and looking for alternative options; iii) to suggest: should propose ideas, practices, solutions, motivate and encourage the realization of projects and classes for which both are responsible together; iv) to encourage: in the context of interpersonal relationship, as the affective load can influence the teacher's emotional balance, as well as his overall attitude towards the professional training process; v) to evaluate: mainly in its formative sense and not only of classification, being essential the specification of the evaluation procedures.

Also Alarcão and Tavares (1987), define some functions of the mentor teacher, emphasizing: establishing and maintaining a good affective-relational climate; developing a spirit of reflection, self-knowledge and innovation; to plan the teaching-learning process of students and the teacher; to determine the aspects to be observed and establish observation strategies; to analyze and to interpret the observed data; to evaluate the teaching-learning processes and to define the action plans to be followed.

When we refer to the functions of the mentor teacher we are also associating them with those of the university teacher, as an element of the supervision process, despite their more specific presence in the cooperating schools. Levine (2011) also suggests two additional 
features that may be needed to promote best practice among supervisory teachers: meet expectations and share information about their role and time frame for collaboration.

According to Mena, Hennissen and Loughran (2017), it is also very relevant to take into account the skills that mentor teachers use in their practices, and to what extent their support can facilitate the acquisition of knowledge and professional development. They also conclude that supervisory skills can lead to effective reflective practice, as long as the process is well defined and deliberately implemented through teacher training programs.

\section{Method}

Methodologically, this is a case study with participant observation, within the scope of the Master's Degree in Teaching Economics and Accounting of the Institute of Education of the University of Lisbon, the only master's degree in Portugal that gives the professional qualification for teaching in secondary education in Economics and Accounting.

In the context of the Bologna Process, the level of professional qualification for teaching became the masters degree, particularly in Portugal. This increase in the qualification of the teaching staff aimed at strengthening the quality of their preparation and enhancing their socio-professional status. The new system of professional qualification for teaching gives special value to the area of professional practice, as the privileged and irreplaceable moment of application of knowledge, skills, competences and attitudes to the real context.

The aim of this study was to analyze the main aspects for a relationship of effective collaboration, reflection and sharing of practices in the process of pedagogical supervision in the initial teacher education.

Based on a qualitative methodological approach, this case study was based on two classes from the last two school years, totaling 24 preservice teachers, 17 mentor teachers and 4 HEI teachers.

The case study methodology is an approach that is well suited to research in education, where the researcher is confronted with complex situations in which it is difficult to select variables, but in which one tries to describe and analyze a phenomenon and its interactions (Yin, 1994).

In addition to the characterization of the classes and contexts, through documental analysis and interviews conducted by the preservice teachers in the schools where they developed the supervised teaching process, the data were collected through participant observation by the HEI teachers. Field notes were made of these observations and also of the informal 
meetings and interviews with the mentor teachers before and after the observation of the classes in the cooperating schools, with descriptive and reflective records, which allowed to record the most subjective part of the observation and to constitute a report of research (Bogdan \& Biklen, 1994). Class observation was supported by purpose-built observation grids.

Data analysis was performed through content analysis, and was subjected to triangulation by diversification of instruments and researchers, since the observation of classes has been carried out on several occasions as a pedagogical pair by HEI teachers, to give greater accuracy in the collection and analysis of the data (Denzin, 1984).

\section{The supervised teaching practice in the Master's Degree in Economics and Accounting Education}

The supervised teaching practice begins with visits to the school, interviews and observation of the work developed by the mentor teacher, which complement the seminars at HEI. The second year is developed with the assistance and teaching of classes, assuming the students progressively the most complete exercise of the teacher's functions.

The work developed by the master's degree seeks to appropriate knowledge and the development of their professional capacities, through planning, teaching, reflection and evaluation activities, which will be supported by the research that the student will describe in a final supervised practice report in a field diary, which includes a description component of observations and a reflective one.

In the leadership and supervision process, the observation of classes, usually by the mentor teacher and sometimes by one ou two HEI teachers, is one of the most important strategies used, since it allows the observation in real context of the development of competences, namely autonomy, relation with the students, reflective and collaborative capacity.

In this process, we followed the guidance of Reis (2011), having developed the necessary procedures so that before the observation of the teachers' training classes, the mentor teacher clarified the objectives of the observation and discussed: the rules for the observation, the integration of this curriculum and planning, the objectives of the class, the strategy and potential evidence for its realization, the possibility of differentiation from some students, the dimensions of observation, and also explain what they would do during observation with date setting and time for the feedback meeting. 
During the observation, the supervising teachers sought to minimize their presence in the room, record their observations according to established standards, record impressions and questions for the feedback meeting. In this meeting, following the defined procedures, they also sought to reconstruct, together with the preservice teacher, the events of the class, to ask him to reflect on what he considers to have gone well in class, what he would like to improve and how, and to mention possible atypical situations. We also took care to describe the observed behaviors rather than evaluate them, as they should be concrete and specific, focus on behavior that the teacher in formation has the capacity to modify, and finally, constructive suggestions were presented.

Throughout the developed supervision process, it is considered important to provide collaborative situations of teaching, assessment and learning, with individual and joint reflections, in order to promote autonomy and shared interaction, contributing to professional development and co- knowledge of the various stakeholders.

\section{Conclusions}

Supervised practice can have a profound impact on teachers in their initial training, depending on whether or not the leadership and oversight process they have involved has influenced them. It must sustain the necessary link between theory and practice and allow the construction of its professional identity.

Despite the evidence found in different contexts about the value of "clinical practice", its impact is mainly determined by the interaction between the various actors (Levine, 2011). Therefore, in the same vein, this study also highlighted the importance of seeking long-term lasting partnerships with experienced mentor teachers from cooperative schools for the training of future teachers and, secondly, to be concerned with the development professional and training of mentor teachers, or even by creating supervising teacher communities.

In this way, clinical practice may also be relevant in terms of its impact on experienced practitioners involved, in particular the benefits they perceive, as they are encouraged to engage critically in sustained research perspectives when in-service teachers and evaluate their own practice (Burn, \& Mutton, 2015).

In summary, this study found the importance of the clarification of the objectives and the process, the joint analysis and reflection of the observed events and the suggestions for constructive improvement offered to the future teachers, as well as the concomitant possibility of professional development of all actors in the process. 


\section{References}

Alarcão, I. \& Tavares, J. (1987). Supervisão da Prática Pedagógica. Uma Perspectiva de Desenvolvimento e Aprendizagem. Coimbra: Almedina.

Azevedo, J. (2012). Nota de apresentação. Revista Portuguesa de Investigação Educacional, 12, 3-5. Porto: Universidade Católica Editora, SA. Retrieved April 26, 2019, from http://www.fep.porto.ucp.pt/sites/default/files/files/FEP/RPIE/RPIE12NotaApresentacao.PDF

Batista, I. (2011). Ética, deontologia e avaliação do desempenho docente. Cadernos do CCAP - 3. Lisboa: Ministério da Educação - Conselho Científico para a Avaliação de Professores. Retrieved from https://repositorio.ucp.pt/handle/10400.14/11641

Bogdan, R. \& Biklen, S. (1994). Investigação Qualitativa em Educação. Uma Introdução à Teoria e aos Métodos. Porto: Porto Editora.

Bond, N. (2011). Preparing Preservice Teachers to Become Teacher Leaders. The Educational Forum, 75(4), 280-297. Retrieved from https://doi.org/10.1080/00131725.2011.602578

Burn, K. \& Mutton, T. (2015). A review of 'research-informed clinical practice' in Initial Teacher Education. Oxford Review of Education, 41 (2), 217-233. Retrieved from http://dx.doi.org/10.1080/03054985.2015.1020104

Denzin, N. (1984). The research act. Englewood Cliffs, NJ: Prentice Hall.

Izadinia, M. (2015). A closer look at the role of mentor teachers in shaping preservice teachers' professional identity. Teaching and Teacher Education, 52, 1-10. Retrieved from http://dx.doi.org/10.1016/j.tate.2015.08.003

Levine, T. H. (2011). Features and strategies of supervisor professional community as a means of improving the supervision of preservice teachers. Teaching and Teacher Education, 27, 930-941. Retrieved from http://dx.doi.org/10.1016/j.tate.2011.03.004

Lu, H.-L. (2010).Research on peer coaching in preservice teacher education - A review of literature. Teaching and Teacher Education, 26, 748-753. Retrieved from http://dx.doi.org/10.1016/j.tate.2009.10.015

Mena, J., Hennissen, P., \& Loughran, J. (2017). Developing pre-service teachers' professional knowledge of teaching: The influence of mentoring. Teaching and Teacher Education, 66, 47-59. Retrieved from http://dx.doi.org/10.1016/j.tate.2017.03.024

Reis, P. (2011). Observação de aula e avaliação do desempenho docente. Cadernos do CCAP - 2. Lisboa: Ministério da Educação - Conselho Científico para a Avaliação de Professores. Retrieved from http://repositorio.ul.pt/handle/10451/4708

Vieira, F. (1993). Supervisão - Uma prática reflexiva de formação de professores. Rio Tinto: Asa. 
Leadership and supervision in pre-service Economics and Accounting teacher education in Portugal

Vieira, F. \& Moreira, M. F. (2011). Supervisão e avaliação do desempenho docente: para uma abordagem de orientação transformadora. Cadernos do CCAP - 1. Lisboa: Ministério da Educação - Conselho Científico para a Avaliação de Professores.

Yin, R. (1994). Case Study Research: Design and Methods (2 ${ }^{\mathrm{a}}$ Ed). Thousand Oaks, CA: SAGE Publications. 